\begin{tabular}{|c|c|c|c|}
\hline & $\begin{array}{r}\text { Anna } \\
\text { http://w }\end{array}$ & $\begin{array}{l}\text { Journal } \\
\text { /index.php }\end{array}$ & \multirow{2}{*}{ 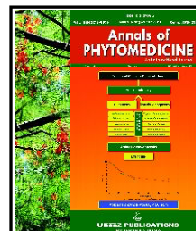 } \\
\hline & Print ISSN : 2278-9839 & Online ISSN : 2393-9885 & \\
\hline
\end{tabular}

Original article

\title{
Comparative phytochemical screening, elemental content and chromatographic evaluation for detection and quantification of polyphenolic compounds for strong antioxidant activity of various extracts of Abutilon indicum (Link) Sweet leaves
}

\author{
Kuntal Das», M. Saifulla Khan, N. Namratha, R. Swetha and Sevgi Gezici**** \\ Department of Pharmacognosy and Phytochemistry, \#12/1, Krupanidhi College of Pharmacy, Chikkabelandur, \\ Carmelaram Post, Varthur Hobli, Bangalore-560035, Karnataka, India. \\ *Advanced Technology Application and Research Center, Kilis 7 Aralik University, Kilis, Turkey. \\ **Department of Molecular Biology and Genetics, Faculty of Arts and Sciences, Kilis 7 Aralýk University, 79000, \\ Kilis, Turkey.
}

Received April 30, 2019: Revised June 19, 2019: Accepted June 22, 2019: Published online June 30, 2019

\begin{abstract}
Abutilon indicum (Link) Sweet (AI) belongs to family Malvaceae. Traditionally, the plant was reported as healer for many ailments and other medicinal values such as leaves are effective against ulcer, laxative, expectorant, diuretic, astringent, analgesic, anti-inflammatory, anthelmintic, demulcent and aphrodisiac. Though, the plant is distributed in tropical and subtropical area, but is became threatened in Karnataka, India due to its habitat lost and over exploitation. The present experiment was carried out with a comparative study to investigate an effect of aqueous and methanol leaves extracts on presence of phytochemicals, vis-a-vis chromatographic evaluation for detection and quantification of gallic acid and quercetin for effective antioxidant activity. Metal ions such as $\mathrm{Fe}, \mathrm{Cu}$, $\mathrm{Zn}, \mathrm{Co}, \mathrm{Ni}, \mathrm{Cd}, \mathrm{As}$, Hg were detected form dried leaves, using Atomic Absorption Spectrophotometer by acid digestion method. Microwave oven extraction was carried out, using both aqueous and methanol as solvents. The percentage yield was calculated and revealed maximum yield with methanol extract $(18.62 \%)$. Various elements such as $\mathrm{Fe}, \mathrm{Zn}$, $\mathrm{Cu}$ were present in high amount in methanolic extract whereas $\mathrm{Co}, \mathrm{Ni}, \mathrm{Cd}, \mathrm{As}, \mathrm{Pb}, \mathrm{Hg}$ were not detected in the leaves. Thereafter, phytochemical screening was carried out with various chemical tests and revealed presence of amino acids, carbohydrates, alkaloids, flavonoids, sterols, phenols and saponins with methanolic extract whereas amino acids, carbohydrates and flavonoids are present in aqueous extract. TLC study revealed presence of gallic acid and quercetin in methanol extract but gallic acid was absent in aqueous extract. Further, quantified by HPLC and showed higher amount of both the constituent in methanol extract (gallic acid $0.45 \mathrm{~g} / 100 \mathrm{~g}$ and quercetin $0.179 \mathrm{~g} / 100 \mathrm{~g}$ ) than aqueous one $(0.019 \mathrm{~g} / 100 \mathrm{~g}$ of quercetin) where absence of gallic acid in aqueous extract. Furthermore, antioxidant study was carried out using DPPH, FRAP assay method and revealed strong free radical scavenging activity with methanol extract which showed positive significant correlation with element contents. Finally, results indicated that methanolic AI extract has strong antioxidant activity, may be due to presence of polyphenolic compounds such as gallic acid and quercetin.
\end{abstract}

Keywords: Abutilon indicum (Link) Sweet, antioxidant, chromatography, elements, phytochemicals

\section{Introduction}

The best and ultimate gift of nature is medicinal plants whether they are available abundantly or rarely that everything depends on the way these plants are utilize by the human. Still, many medicinal plants are available whose medicinal values are unknown and some natural plants are became threatened or endangered due to natural calamity or due to their habitat lost naturally or due to over exploitation, but such plants have greater medicinal values. It is obvious that medicinal values depend on presence of

\footnotetext{
Author for correspondence: Dr. Kuntal Das

Professor, Department of Pharmacognosy and Phytochemistry, \#12/ 1, Krupanidhi College of Pharmacy, Chikkabelandur, Carmelaram Post, Varthur Hobli, Bangalore-560035, Karnataka, India

E-mail: drkkdsd@gmail.com

Tel.: +91-9632542846
}

Copyright () 2019 Ukaaz Publications. All rights reserved.

Email: ukaaz@yahoo.com; Website: www.ukaazpublications.com phytoconstituents in plants. The phytoconstituents are also known as plant secondary metabolites which are available in less quantity in plants. The availability of these plant secondary metabolites are mainly depend on minerals uptakes by the plant.

Looking at all these important aspects in the present study, Abutilon indicum (Link) Sweet (AI) plant was selected. The plant is commonly known as Indian mallow, originated in India and is commonly located in many states of India (Kirtikar and Basu, 1994). In hot temperate zone, the plant is mainly distributed but due to habitat lost, this plant became endangered especially in Karnataka, India. Whereas, in Karnataka, the plant is endangered in many places likely Bangalore, Bijapur, Gulbarga, Hassan, Kolar, Raichur, Udupi and Tumkur. Hence, it is worthwhile to select this plant for the present study. Traditionally, it was reported that the plant has medicinal values such as leaves are effective against ulcer and as a fomentation 
to painful parts of the body. The leaves decoction is used in toothache, tender gums and internally for inflammation of bladder. Roots are effective as demulcent, diuretic, in chest infection and urethritis. The bark is used as febrifuge, anthelmintic, alexeteric, astringent and diuretic whereas seeds are used as expectorant, laxative, piles, etc. (Nadakarni, 1995; Sharma et al., 2013). These activities are due to the presence of secondary metabolites in the plant. It is seen that leaves are the place where all elements and minerals are stored via uptake by roots and, hence leaves are the main place where availability of active principles are more and based on that in the present study, leaves of AI were selected. Thereafter, it is worthwhile to know about the elements present in the leaves, so that it is easy to correlate the content of elements with the stored constituents along with therapeutic efficacy. Scientifically, it was proved that plant constituents in extract are depend on type of extraction method as well as a choice of solvents. Various chemical tests, TLC chromatogram helps in separation and identification of plant constituents and HPLC will help for separation and quantification of the individual components from the plant extract. Based on that concept, isolation and quantification by chromatographic methods are necessary for further investigation. With this idea in the present study, TLC followed by HPLC was performed for separation and quantification of particular constituents for antioxidant activity. Finally, correlation between elements, yield and antioxidant study were compared and reported scientific data for future researches which are lacking for this $\mathrm{AI}$ plant. Many research papers revealed that AI plant has various pharmacological activities such as diuretic activity of AI seeds (Balamurugan et al., 2010), antioxidant, hypoglycaemic, immunomodulatory, Anti-diarrhoeal activities of leaves of AI, respectively (Chakraborthy, 2009; Seetharam et al., 2002; Dashputre et al., 2010; Chandrashekhar et al., 2000), analgesic activity of AI root extract (Goyal et al., 2009), antioxidant activity of AI stem (Chakraborthy and Ghorpade, 2009) and so on. But, there is a research gap on impact of metal ions in dried leaves on the presence of phytochemicals, especially polyphenolic compounds (gallic acid and quercetin) which are responsible for antioxidant activity. Hence, the present investigation was carried out to fill this grey area on AI plant by compared with methanol and aqueous leaves extracts and established authentic scientific data for drug discovery towards treatment of rare human diseases.

\section{Materials and Methods}

\subsection{Collection of plants and authentication}

AI plant was procured from Nandi hills in Chikkaballapur Dist, $60 \mathrm{Km}$ away from Bangalore, Karnataka (Longitude and latitude: $77.7009344^{\circ} \mathrm{E}$ and $13.3862588^{\circ} \mathrm{N}$, respectively). Leaves of the plant were collected in the month of November (starting of flowering), 2018 and was authenticated by Dr. P.E. Rajashekaran, Principal Scientist, Indian Institute of Horticultural Research, Hessaraghatta, Bangalore. The leaves of the AI were kept as future reference in herbarium of Pharmacognosy Department of Krupandihi College of Pharmacy, Bangalore (Herberium No: KCP/Abutilon indicum404/PCOG-NAMRATHA/2018-19) (Figure 1).

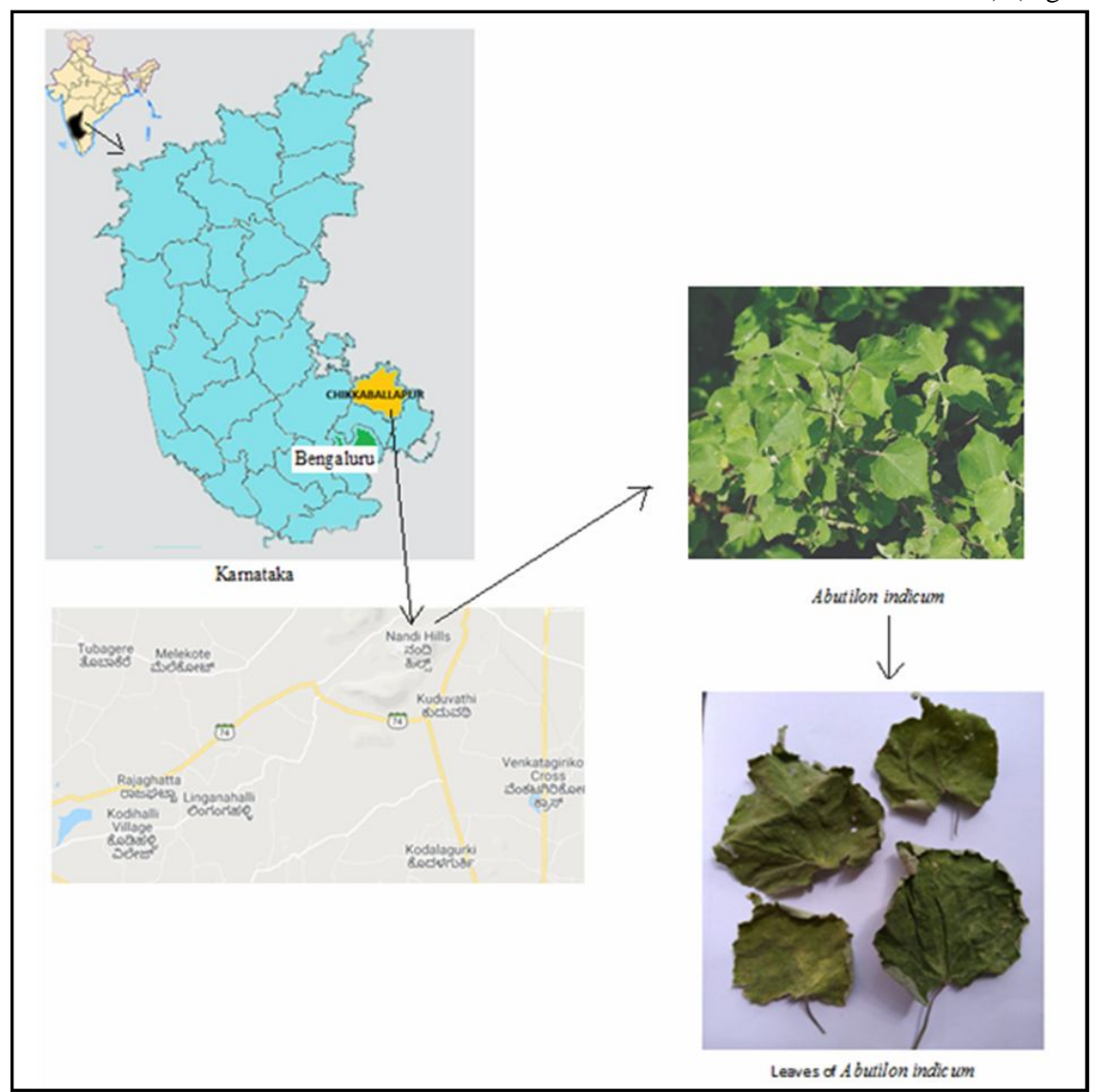

Figure 1: Location and collection of A. indicum plants. 


\subsection{Processing and drying}

Leaves were separated from the stem of AI plants. Cleaned with running tap water and removed the dusts and other foreign matters. Then, the leaves were spreaded on working slab on the Pharmacognosy laboratory and shade dried for 14 days and grinded by using mixer grinder to made coarse powder. Powdered drugs were then stored in moisture free plastic sealed cover for further experimentation.

\subsection{Extraction of AI leaves}

A microwave oven (LG Electronics, India, Model MG-556 P, 1350 W, $2450 \mathrm{MH}_{\mathrm{Z}}$ ) was used for extraction of plant samples. Temperature was the preferred controlled variable to avoid degradation of the target compounds and to achieve the maximum efficiency. $100 \mathrm{~g}$ of leaves of AI was treated with methanol and aqueous solvents separately (100 $\mathrm{ml}$ for each case) and extracted by microwave assisted extractor and irradiated up to $25 \mathrm{~min}$ at $70^{\circ} \mathrm{C}$ with stirring. After the samples were taken out, cooled and then extract was filtered separately with Whatman no. 1 filter paper. Finally, extracts were evaporated separately with the rotary flash evaporator at $45^{\circ} \mathrm{C}$ and stored at $4{ }^{\circ} \mathrm{C}$ in glass bottles. The yield was determined separately.

\subsection{Metal ion analysis}

Extracted samples (5 mg) separately were mixed with diacid mixtures (10 ml Conc. Sulphuric acid and $40 \mathrm{ml}$ conc. perchloric acid) and digestion was carried out at $200^{\circ} \mathrm{C}$ until dense white fumes of acids were evolved to get white residue. Subsequently, the digested samples were diluted with deionized water and volume made up to $50 \mathrm{ml}$. Final solutions were analyzed for metal contents such as Fe, $\mathrm{Cu}, \mathrm{Zn}, \mathrm{Co}, \mathrm{Ni}, \mathrm{Cd}, \mathrm{As}, \mathrm{Pb}, \mathrm{Hg}$ by using Atomic Absorption Spectrophotometer (Perkin Elmer model: A Analyst 100; Australia). Air-acetylene was used as the common oxidant and the concentration of the above said metals was determined by using the standard condition. Blank sample was prepared for reading corrections. All the samples were analyzed in triplicate for the reproducibility of the method used.

\subsection{Phytochemical screening}

The presence of various phytochemicals were screened qualitatively by various chemical tests for the detection of plant constituents such as carbohydrates, proteins, amino acids, alkaloids, flavonoids, steroids, tannins, glycosides, terpenoids and others as methods described by following standard methods (Harborne, 1998; Evans, 2002) and the results were presented in result section.

\subsection{Thin layer chromatography (TLC)}

Based on the plant secondary metabolites present and their effects on antioxidant activity, the present study was selected to separate polyphenolic compounds such as gallic acid and quercetin which are having strong antioxidant activity. Various solvent systems were applied for clear separation of the constituents and finally toluene, ethyl acetate and formic acid combination was selected for detection and separation of said compounds.

\subsection{HPLC analysis}

Quantification of above said compounds were carried out using RP-HPLC study.
Mobile phase preparation: Mobile phase was prepared by mixing Methanol: Water (70:30). This solution was filtered using a 0.45 micron Millipore filter paper and was sonicated for $10 \mathrm{~min}$. The total volume of the mobile phase prepared was $500 \mathrm{ml}$.

Standard preparation: $10 \mathrm{mg}$ of standard gallic acid and quercetin was taken separately (Gift samples were procured from Sun Biologicals, Bansankari $2^{\text {nd }}$ stage, Bangalore, India) in $10 \mathrm{ml}$ volumetric flask and make up the volume to $10 \mathrm{ml}$ with respective solvents (the concentration of this solution is $1000 \mu \mathrm{g} / \mathrm{ml}$ ). The solution was sonicated for $8 \mathrm{~min}$ and then filtered using 0.45 micron millipore filters.

Sample preparation: $10 \mathrm{mg}$ of the extracted sample was diluted with the respective solvent $(10 \mathrm{mg} / \mathrm{ml})$. The solution was vortex for $5 \mathrm{~min}$. The sample was filtered using 0.45 micron millipore filters and $20 \mu 1$ of the sample was injected in the HPLC system.

\section{Optimized chromatographic conditions}

\begin{tabular}{|c|c|}
\hline Detector & : Shimadzu spd10A uv-vis, Japan \\
\hline Pump & : Shimadzu LC-10ATVP, Japan \\
\hline \multicolumn{2}{|c|}{ Injection valve : 7725 i Rheodyne $20 \mu$, USA } \\
\hline Syringe & : $50 \mu 1$ Hamilton, Switzerland, \\
\hline Column & : Phenomenex Gemini NX-5 $\mu \mathrm{m} \mathrm{C}_{18} 110 \AA$ \\
\hline Dimensions & $: 250 \times 4.6 \mathrm{~mm} \mathrm{ID}$ \\
\hline Elution Type & : Isocratic \\
\hline Elution A & : Methanol \\
\hline Elution B & : Methanol : water (60:40) \\
\hline Flow Rate & $: 1 \mathrm{ml} / \mathrm{min}$ \\
\hline Col. Temp & : ambient \\
\hline Detection & : UV-Vis at $203 \mathrm{~nm}$ \\
\hline Software & : Baseline chromatography data system N2000 \\
\hline Calculation & \\
\hline
\end{tabular}

The concentration of unknown sample was calculated which is as follows:

$=$ Sample area/ STD area $\times$ STD wt. $/$ Sample wt. $x$ Sample dilution /STD dilution $\mathrm{x}$ purity $/ 100 \times 100$

\section{Linearity measurement}

The stock solution of the standard $(1 \mathrm{mg} / \mathrm{ml})$ was diluted to six different concentrations $(5,10,20,30,40,60 \mu \mathrm{g} / \mathrm{ml})$ which were injected individually to the HPLC system and the calibration curve so obtained by plotting peak area versus concentration for each sample (in triplicates). The correlation coefficient $\mathrm{R}^{2}>0.998$ is indicative of the measure of linearity.

\section{Precision}

It indicates the degree of proximity of the results expressible as \% relative standard deviation (RSD) between peak areas with retention time. The repeatability of the retention time and peak areas were checked by injecting the mixed standard solutions based on the any two selected concentration levels (form linearity concentrations: $20 \mu \mathrm{g} / \mathrm{ml}$ and $40 \mu \mathrm{g} / \mathrm{ml}$ ) into the HPLC system. The RSD of retention time and peak areas were calculated for three replicate determinations. 


\subsection{Antioxidant study}

\subsubsection{DPPH method}

DPPH (2,2-diphenyl-1-picrylhydrazyl hydroxyl) assay was performed based on the earlier method (Chen et al., 2016). Two ml of each extract was vortexed separately with DPPH solution $(5 \mathrm{ml} /$ $0.1 \mathrm{mM}$ ). This mixture was incubated in the dark for $30 \mathrm{~min}$ at room temperature and absorbance was measured against blank at 517 $\mathrm{nm}$. The decrease in absorption was correlated with the per cent inhibition of samples and gallic acid was used as standard. Finally, the percentage inhibition of DPPH was calculated by the formula:

$$
\% \text { Inhibition }=\frac{\text { Absorbance } b l a n k-\text { Absorbance }}{\text { sample }} \underset{\text { Absorbance }}{\text { blank }} \times 100
$$

\subsubsection{FRAP (Ferric ion reducing antioxidant power) method}

In this method, $2.0 \mathrm{ml}$ of each extract and potassium ferricyanide $(0.1 \%)$ were mixed in triplicate in phosphate buffer $(0.2 \mathrm{M} / \mathrm{pH} 6.6)$. Subsequently, this mixture was placed in a water bath at $50^{\circ} \mathrm{C}$ for $20 \mathrm{~min}$ and trichloroacetic acid ( $2 \mathrm{ml}$ of $10 \%$ solution) was added. To the supernatant, distilled water and $0.01 \%$ ferric chloride $(2 \mathrm{ml}$ of each) were mixed gently and then kept at room temperature for $20 \mathrm{~min}$ before taking absorbance at $700 \mathrm{~nm}$. Final values were expressed as gallic acid equivalent per $100 \mathrm{~g}$ based on fresh weight of the sample ( $\mu \mathrm{M} \mathrm{GAE} / 100 \mathrm{~g} \mathrm{FW}$ ) (Chen et al., 2016).

\subsection{Correlation study}

Correlation study was performed along with practical yield and metal content in extracts of AI. Thereafter, yield was correlated with quantification of the constituent present in the sample. Finally, metal ion content, yield, and quantified constituents were all correlated with the antioxidant activity for inner mechanism established for the effects of solvents and yield on any therapeutic activity.

\section{Statistical analysis}

Data were presented as Mean \pm SD for all triplicate analysis. The data were subjected to a one-way analysis of variance (ANOVA) and the significance of the difference between means was calculated by Tukey's multiple comparison test. The $p<0.05$ was considered statistically significant.

\section{Results}

\subsection{Yield of the extract}

Yield of the AI leaves was calculated for both the methanolic and aqueous extracts and resulted higher yield with methanolic extract than aqueous extract when extracted with Micro-oven extraction method (Figure 2).

\subsection{Content of metal ions}

Atomic Absorption Spectrophotometer was used for determination of metal contents ( $\mathrm{Fe}, \mathrm{Cu}, \mathrm{Zn}, \mathrm{Co}, \mathrm{Ni}, \mathrm{Cd}, \mathrm{As}, \mathrm{Pb}, \mathrm{Hg}$ ) in the dried leaves of AI. Results revealed that high content of $\mathrm{Fe}, \mathrm{Zn}$ and $\mathrm{Cu}$ in the leaves whereas $\mathrm{Ni}$ content was found below the risk factor and other non-essential metals such as $\mathrm{Co}, \mathrm{Cd}, \mathrm{As}, \mathrm{Pb}$ and $\mathrm{Hg}$ are below detectable limits (Table 1). It indicated that Fe content $(5.28 \mathrm{mg} /$ $\mathrm{kg}), \mathrm{Zn}$ content $(2.10 \mathrm{mg} / \mathrm{kg})$ and $\mathrm{Cu}$ content $(1.06 \mathrm{mg} / \mathrm{kg})$ of dried leaves.

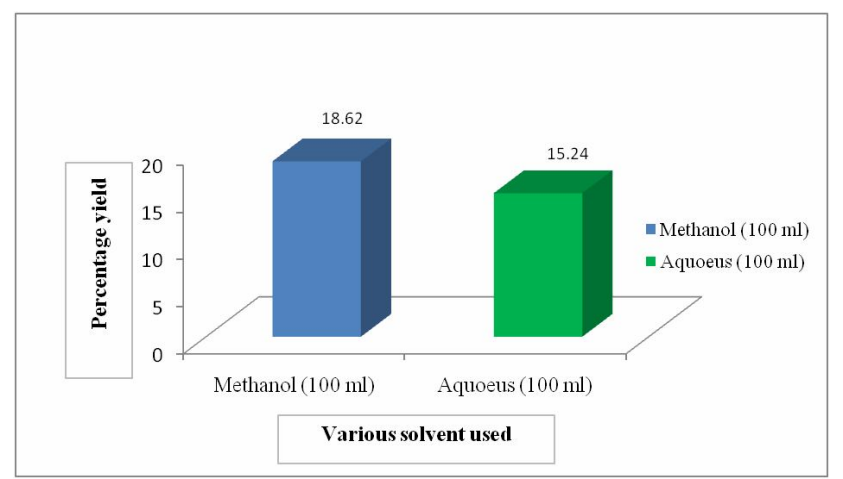

Figure 2: Percentage yield of the extract in various solvents.

Table 1: Metal content in dried leaves of AI

\begin{tabular}{|c|c|c|}
\hline $\begin{array}{c}\text { Metal contents } \\
\text { in leaves }\end{array}$ & MEAI & AEAI \\
\cline { 2 - 3 } & AI $(\mathbf{m g} / \mathbf{k g})$ & AI $(\mathbf{m g} / \mathbf{k g})$ \\
\hline $\mathrm{Fe}$ & $5.28 \pm 0.02$ & $2.01 \pm 0.04$ \\
$\mathrm{Zn}$ & $2.10 \pm 0.13$ & $1.00 \pm 0.11$ \\
$\mathrm{Cu}$ & $1.06 \pm 0.11$ & $0.11 \pm 0.03$ \\
$\mathrm{Ni}$ & $0.02 \pm 0.10$ & $0.05 \pm 0.02$ \\
$\mathrm{As}$ & Not detectable & Not detectable \\
$\mathrm{Cd}$ & Not detectable & Not detectable \\
$\mathrm{Hg}$ & Not detectable & Not detectable \\
$\mathrm{Pb}$ & Not detectable & Not detectable \\
$\mathrm{Co}$ & Not detectable & Not detectable \\
\hline
\end{tabular}

Mean \pm SD $(n=3)$; MEAI = Methanolic extract of AI; AEAI = Aqueous extract of $\mathrm{AI}$.

\subsection{Phytochemical screening}

Details chemical tests were carried out with two different extracts. It was resulted maximum group of the phytoconstituents were present in the methanol extract than aqueous extract. Result was tabulate in Table 2. It was indicated that amino acids, carbohydrates, alkaloids, flavonoids, sterols, phenols and saponins are present with methanolic extract whereas amino acids, carbohydrates and flavonoids are present in aqueous extract.

Table 2: Phytochemical screening of AI extracts

\begin{tabular}{|l|c|c|}
\hline Phytoconstituents & MEAI & AEAI \\
\hline Amino acids & ++ & + \\
Carbohydrates & + & ++ \\
Glycosides & -- & -- \\
Alkaloids & ++ & -- \\
Flavonoids & ++ & ++ \\
Sterols & ++ & -- \\
Phenols & ++ & -- \\
Saponins & ++ & -- \\
Terpenoids & -- & -- \\
Resins & -- & -- \\
\hline
\end{tabular}

MEAI = Methanol extract of AI; AEAI = Aqueous extract of AI; (+) = Present; (--) Absent

\subsection{TLC}

Based on the phytochemical screening, further TLC was performed for the identification and separation of the active components. It 
was observed that toluene, ethyl acetate and formic acid with the ratio of 5: 4: 0.2 gave better separation of the quercetin flavonoid whereas combination of same solvent with the ratio of 7: 5: 1 was better for gallic acid separation. In case of methanol extract, both gallic acid and quercetin were visible prominently (under UV 366 $\mathrm{nm}$ ) whereas less visible of quercetin in aqueous extract and no spot was found for gallic acid (Figure 3, Table 3).

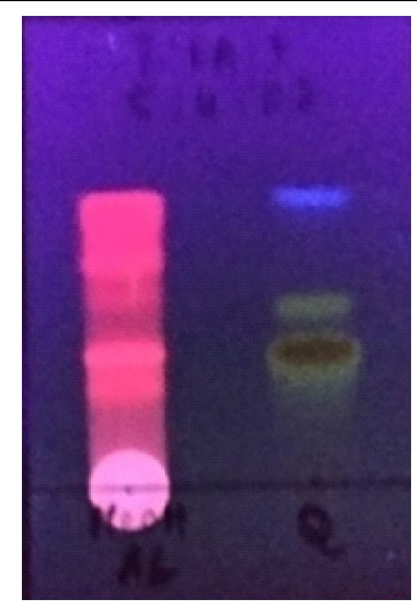

TLC of methanolic AI

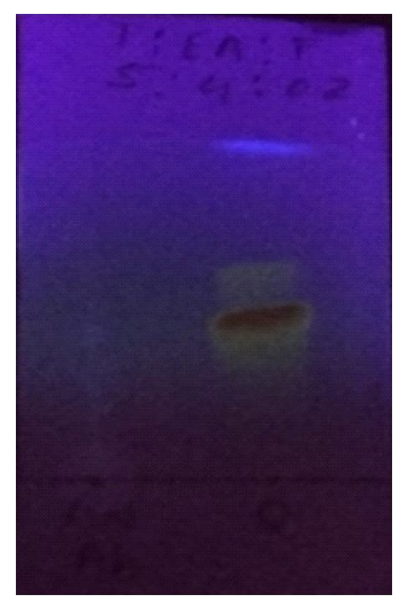

TLC of aqueous AI
Figure 3(a): TLC of aqueous and methanolic AI extract compared with standard quercetin.

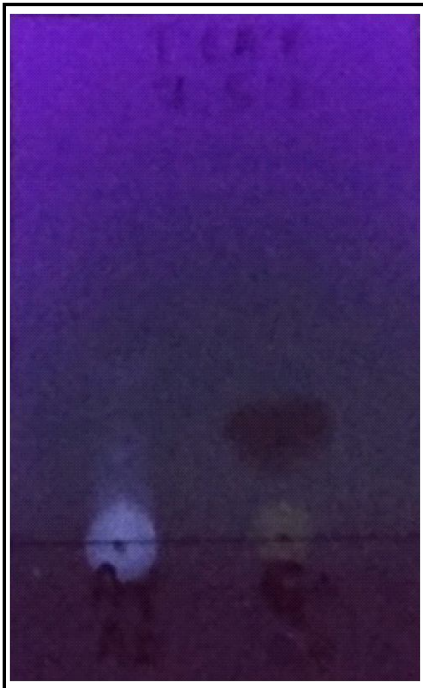

TLC of Aqueous AI

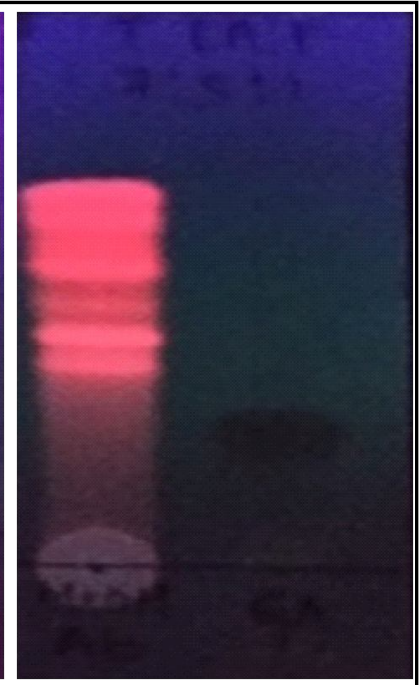

TLC of methanolic AI
Figure 3(b): TLC of aqueous and methanolic AI extract compared 4.5 HPLC study with standard gallic acid.

Further, quantification of the constituents through HPLC was studied and resulted methanolic extract showed more content of gallic acid $(0.45 \mathrm{~g} / 100 \mathrm{~g})$ and quercetin $(0.179 \mathrm{~g} / 100 \mathrm{~g})$ which were higher than aqueous extract $(0.019 \mathrm{~g} / 100 \mathrm{~g}$ of quercetin) when experiment was carried out UV at $203 \mathrm{~nm}$ (Figure 4). Gallic acid was not detectable in the aqueous extract. The retention time (Rt) for the quercetin and gallic acid in methanolic extract showed same as per standards (Figure 5).

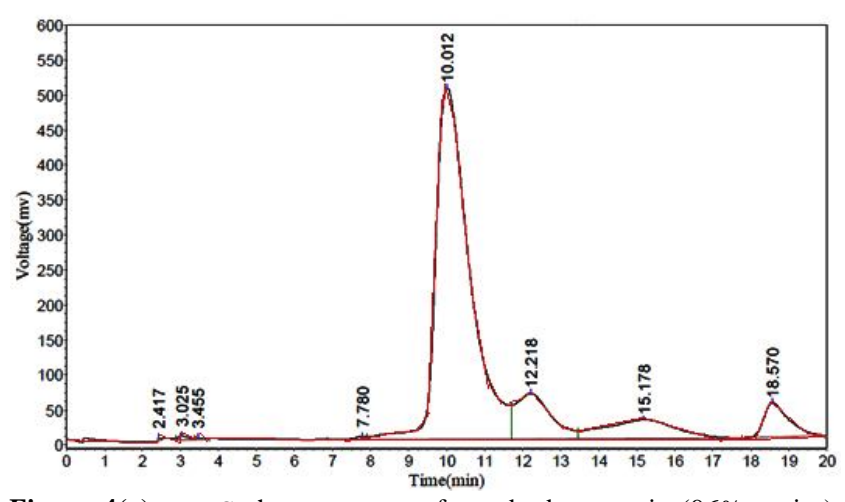

Figure 4(a): HPLC chromatogram of standard quercetin (96\% purity).

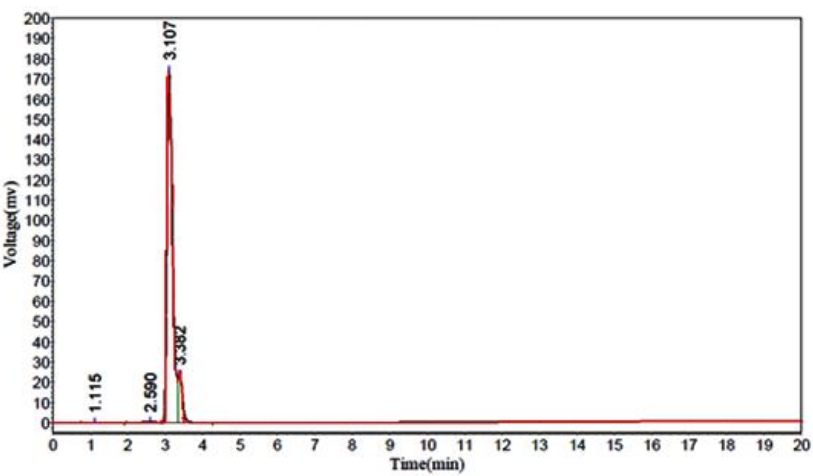

Figure 4(b): HPLC chromatogram of standard gallic acid (98\% purity).

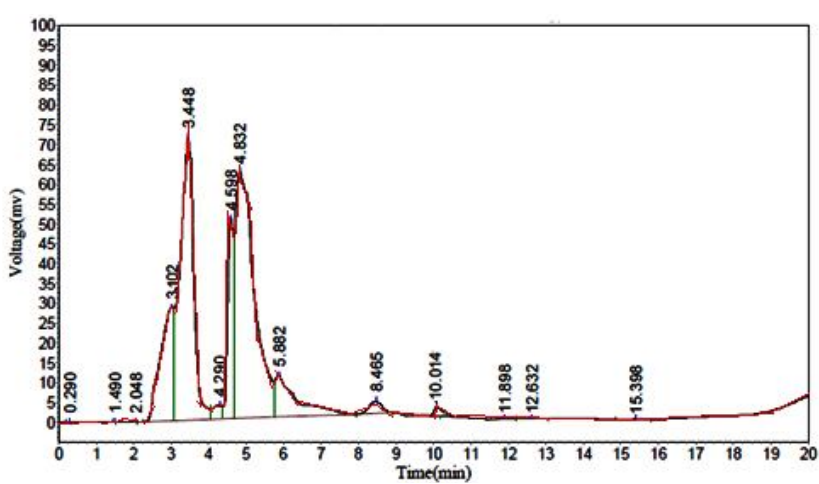

Figure 5(a): HPLC chromatogram of AI methanol extract.

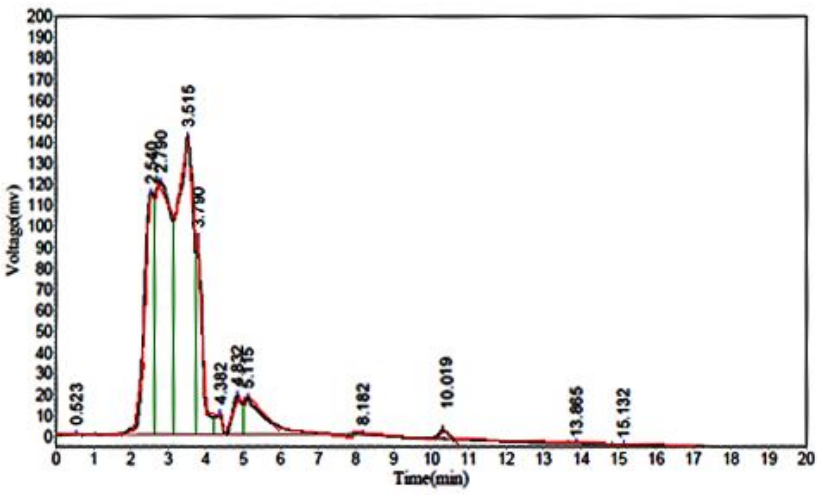

Figure 5(b): HPLC chromatogram of AI aqueous extract. 
Table 3: Analysis of extracts with TLC chromatogram

\begin{tabular}{|l|l|c|l|c|}
\hline \multirow{2}{*}{ Extracts } & \multicolumn{2}{|c|}{ Quercetin } & \multicolumn{2}{c|}{ Gallic acid } \\
\cline { 2 - 5 } & Spot (UV 366 nm) & Rf & Spot (UV 366 nm) & Rf \\
\hline MEAI & $\begin{array}{l}\text { Pink spot coincided } \\
\text { with green spot }\end{array}$ & 0.4 & $\begin{array}{l}\text { Pink spot coincided } \\
\text { with black spot }\end{array}$ & 0.37 \\
AEAI & $\begin{array}{l}\text { Light blue spot } \\
\text { coincided with } \\
\text { green spot }\end{array}$ & 0.5 & Not identified & -- \\
\hline
\end{tabular}

Table 4: Retention time and calibration parameters of calibration curve, precision and repeatability of quercetin and gallic acid.

\begin{tabular}{|l|c|c|c|c|}
\hline Standards & $\begin{array}{c}\text { Wave } \\
\text { length } \\
\text { (nm) }\end{array}$ & $\begin{array}{c}\text { Retention } \\
\text { time } \\
\text { (Rt: } \mathbf{m i n s})\end{array}$ & $\begin{array}{c}\text { \% RSD } \\
\text { of the } \\
\text { Rt }\end{array}$ & $\begin{array}{c}\text { Regression } \\
\text { coefficient } \\
\text { (R²) }^{2}\end{array}$ \\
\hline Quercetin & 203 & 10.012 & 0.854 & 0.998 \\
Gallic acid & 203 & 3.107 & 0.803 & 0.997 \\
\hline
\end{tabular}

The high value of $\mathrm{R}^{2}>0.998$ in the range of analyzed concentrations at $203 \mathrm{~nm}$ was indicative of linearity for both the extracts separately. The percentage RSD of the retention time for both the standards (quercetin and gallic acid) was $<1 \%$ (Table 4 ).

\subsection{Antioxidant study}

DPPH radical scavenging assay was applied for basic antioxidant study of the AI extracts. Results were depicted in Figure 6 which indicated that methanolic extract exhibited little higher antioxidant activity than aqueous extract.

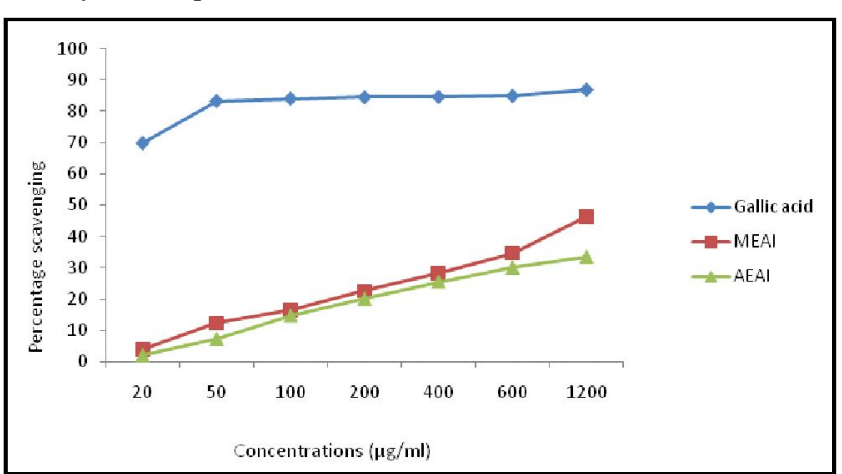

Figure 6: DPPH radical scavenging activity of AI methanol and aqueous extracts (values are average of triplicate experiment and are represented as Mean $\pm \mathrm{SD}$ ).

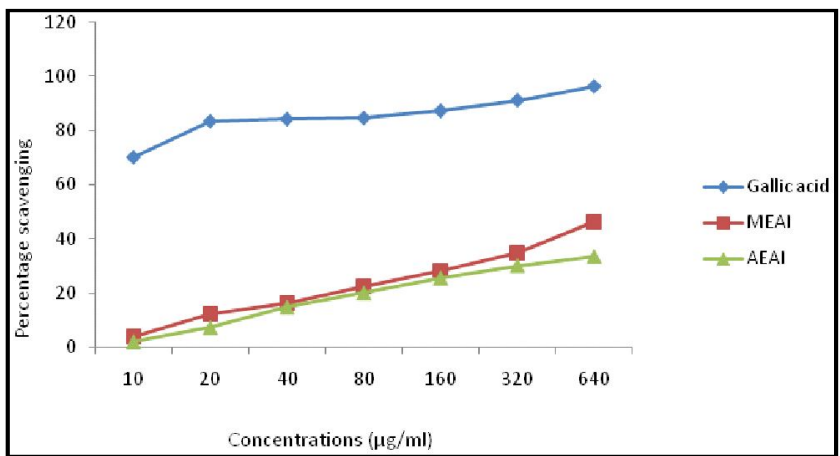

Figure 7: FRAP assay method of AI methanol and aqueous extracts. (values are average of triplicate experiment and are represented as Mean $\pm \mathrm{SD}$ ).
In another FRAP assay method, the same result was obtained (Figure 7) when compared with the standard gallic acid.

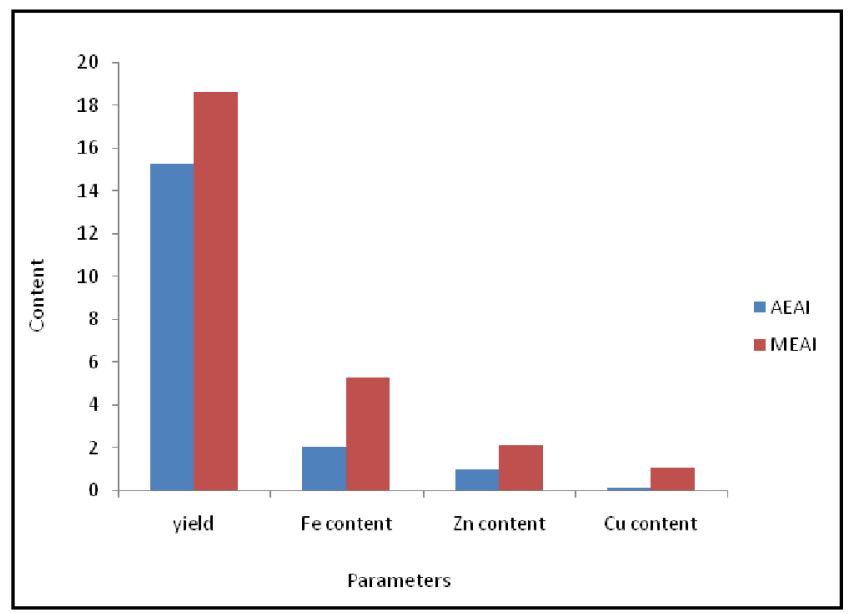

Figure 8: Correlation study of yield with metal content in AI extracts.

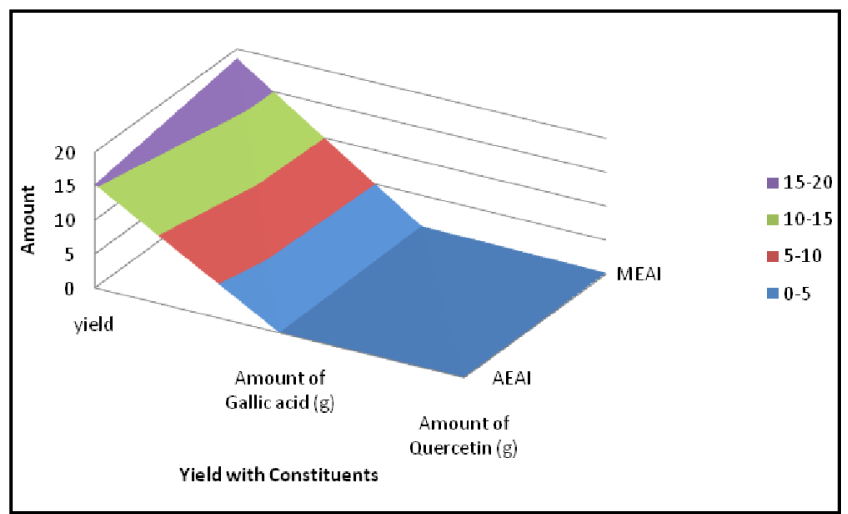

Figure 9: Correlation study of constituents with yield.

\subsection{Correlation study}

Methanolic yield was correlated with element contents in the two different extracts and revealed positive correlation with the yield that was obtained from methanolic extract than aqueous extract of AI leaves (Figure 8). Further, yield was correlated with the quantified gallic acid and quercetin and also revealed the same results where methanolic extract showed higher than aqueous one (Figure 9). Finally, yields amount of the constituent, metal ion content were correlated with antioxidant study and result was presented in Table 5. Table indicated that methanolic yield was highly significant with quercetin present in methanol extract $\left({ }^{* * *} p<0.001\right)$ and also correlated with DPPH and FRAP assay of methanolic extracts $(" p<0.05)$. Thereafter, quercetin present in methanolic extract was also significantly correlated with DPPH and FRAP assay for antioxidant $\left({ }^{*} p<0.05\right)$ of methanolic extract. Furthermore, methanolic extract showed high significant correlation between DPPH and FRAP assay $\left({ }^{* * *} p<0.001\right)$. Based on that further metal ion contents in methanolic extract was correlated with constituents present and antioxidant studies of methanolic extract and tabulated in Table 6 which indicated positive significant correlation of constituents and antioxidant studies with $\mathrm{Fe}$ (Iron) content whereas $\mathrm{Zn}$ and $\mathrm{Cu}$ contents were non-significant. 
Table 5: Correlation study of yield, constituent and antioxidant effect

\begin{tabular}{|c|c|c|c|c|c|c|c|c|c|}
\hline & $\begin{array}{c}\text { Yield in } \\
\text { MEAI }\end{array}$ & $\begin{array}{c}\text { Yield in } \\
\text { AEAI }\end{array}$ & $\begin{array}{l}\text { Quercetin } \\
\text { in MEAI }\end{array}$ & $\begin{array}{c}\text { Quercetin } \\
\text { in AEAI }\end{array}$ & $\begin{array}{c}\text { Gallic acid } \\
\text { in MEAI }\end{array}$ & $\begin{array}{c}\text { DPPH } \\
\text { of MEAI }\end{array}$ & $\begin{array}{c}\text { DPPH } \\
\text { of AEAI }\end{array}$ & $\begin{array}{c}\text { FRAP } \\
\text { of MEAI }\end{array}$ & $\begin{array}{c}\text { FRAP } \\
\text { of AEAI }\end{array}$ \\
\hline Yield in MEAI & 1 & & & & & & & & \\
\hline Yield in AEAI & 0.674 & 1 & & & & & & & \\
\hline Quercetin in MEAI & $1.00^{* * * *}$ & 0.674 & 1 & & & & & & \\
\hline Quercetin in AEAI & 0.302 & 0.447 & 0.302 & 1 & & & & & \\
\hline Gallic acid in MEAI & 0.853 & 0.632 & 0.853 & -- & 1 & & & & \\
\hline DPPH of MEAI & $0.944^{*}$ & 0.600 & $0.944^{*}$ & 0.447 & 0.632 & 1 & & & \\
\hline DPPH of AEAI & 0.455 & 0.405 & 0.455 & -0.302 & 0.853 & 0.135 & 1 & & \\
\hline FRAP of MEAI & $0.944^{*}$ & 0.600 & $0.944^{*}$ & 0.447 & 0.632 & $1.00^{* * * *}$ & 0.135 & 1 & \\
\hline FRAP of AEAI & 0.561 & 0.832 & 0.561 & -0.169 & 0.239 & 0.680 & -0.153 & 0.680 & 1 \\
\hline
\end{tabular}

**** $p<0.001=$ High significant; ${ }^{*} p<0.05=$ Significant; AEAI $=$ Aqueous extract of AI; MEAI= Methanol extract of AI

Table 6: Correlation study of metal ions, constituent and antioxidant effect of MEAI

\begin{tabular}{|c|c|c|c|c|c|c|c|}
\hline & $\begin{array}{l}\text { Fe in } \\
\text { MEAI }\end{array}$ & $\begin{array}{l}\text { Zn in } \\
\text { MEAI }\end{array}$ & $\begin{array}{l}\text { Cu in } \\
\text { MEAI }\end{array}$ & $\begin{array}{c}\text { Quercetin } \\
\text { in MEAI }\end{array}$ & $\begin{array}{c}\text { Gallic acid } \\
\text { in MEAI }\end{array}$ & $\begin{array}{c}\text { DPPH } \\
\text { in MEAI }\end{array}$ & $\begin{array}{c}\text { FRAP } \\
\text { in MEAI } \\
\end{array}$ \\
\hline $\mathrm{Fe}$ in MEAI & 1 & & & & & & \\
\hline $\mathrm{Zn}$ in $\mathrm{MEAI}$ & -0.200 & 1 & & & & & \\
\hline $\mathrm{Cu}$ in MEAI & -0.632 & -0.632 & 1 & & & & \\
\hline Quercetin in MEAI & $0.944^{*}$ & 0.135 & -0.853 & 1 & & & \\
\hline Gallic acid in MEAI & 0.632 & 0.632 & -1.00 & 0.853 & 1 & & \\
\hline DPPH in MEAI & $1.00^{* * * *}$ & -0.200 & -0.632 & $0.944^{*}$ & 0.632 & 1 & \\
\hline FRAP in MEAI & $1.00^{* * * *}$ & -0.200 & -0.632 & $0.944^{*}$ & 0.632 & $1.00^{* * * *}$ & 1 \\
\hline
\end{tabular}

**** $p<0.001=$ High significant; ${ }^{*} p<0.05=$ Significant; MEAI $=$ Methanol extract of AI

\section{Discussion}

The yield of the AI varied with the solvent used in the present study. It was observed that methanolic extract gave higher yield than aqueous extract. The selection of solvent system as well as the extraction method has significant impact on content of extract and their respective final yield. Furthermore, yield is dependent on solubility of the constituents in the suitable solvent. There are many research evidences on selection of solvent and methods that increase the yield of the extract (Das et al., 2016; Dhanani et al., 2017; Adhikari et al., 2018). In the present study, microwave extraction method was applied using less solvent and less time spent with effective higher yield. Earlier many research articles are the evidences for positive application of microwave extraction for plant material extraction (Saleh et al., 2017; Alara et al., 2018; AlMamoori and Al-Janabi, 2018). Based on that concept, in this investigation, microwave extraction gave higher yield in less time and with less solvent application.

Thereafter, it was necessary to identify and determine the metal ion content in the extract of selected plant (AI) because metal ions help in increase in percentage of constituents present in the plant. Especially, the main storage house of plant is leaves because any kind of soil minerals or any other metal ions are uptakes by roots and through xylem and phloem of the stem, the soluble form of metals are stored in the leaves and as per requirement, these soluble minerals and metals are distributed whole parts of the plants. Furthermore, some toxic heavy metals are also stored in the plant body which are most essential to identify and quantify to establish the safety data for therapeutic efficacy. Earlier few research papers revealed some importance of metal ion detection in plants and showed positive correlation with the yield, enhancement of the secondary metabolites as well as improve therapeutic efficacy (Das et al., 2011; Das and Tribedi, 2015; Das et al., 2016) and the same trend was followed in this present investigation. In this experiment, $\mathrm{Fe}, \mathrm{Zn}$ and $\mathrm{Cu}$ metals were quantified for the importance in plant growth. Iron plays a significant role in various physiological and biochemical pathways in plants by involvement in the synthesis of chlorophyll. Not only that, it is also essential for the maintenance of chloroplast structure and function, DNA synthesis, respiration, and photosynthesis (Das, 2007; Rout and Sahoo, 2015). Same way, $\mathrm{Cu}$ also helps in various physiological functions in plants and an essential cofactor for many metalloproteins. It is actively associated with photosynthetic electron transport, mitochondrial respiration and cell wall metabolism (Raven et al., 1999; Das et al., 2011). In plants, zinc plays an important role as a structural constituent or regulatory co-factor of a wide range of different enzymes. It is necessary element for maintain living membranes and it is also connected to membrane phospholipids or constituent groups of sulfhydryl or forms chelate and thus, proteins and lipids were protected against oxidation damage (Marschner, 1995; Mousavi et al., 2013). Based on these research reviews, the present investigation also showed the positive effects on yield of AI extract in methanol solvent.

Thereafter, phytochemical screening for both the methanol and aqueous extracts was carried out using various chemical tests and revealed maximum constituents are positive in methanol extracts than aqueous extract. This may be due to the solubility of the phytoconstituents in the solvent and the choice of the method for the extraction which was similar to that of earlier research reviews (Sulaiman et al., 2015; Durgawale et al., 2019). 
Thereafter, TLC and HPLC methods were carried out for identification, separation and finally quantification of plant constituents. In the present study, phenolic compound, gallic acid and flavonoid quercetin were identified by TLC and quantified by HPLC. The main interest for these polyphenolic compounds to identify for an antioxidant activity of the said plant. Quescetin (flavanoid compound) was found in both the extracts (methanol and aqueous extracts) as it gave a pink spot when viewed under UV transilluminator at $366 \mathrm{~nm}$. A poly phenolic compound, gallic acid was found in methanol extract while absent in aqueous extract. Hence, it was confirmed that methanolic extract was better for TLC separation to identifiy the desired compounds which was similar to that of earlier research reports (Biradar and Rachetti, 2013; Mehta et al., 2017). HPLC is an accurate and specific method for the identification and quantification of phenolic acids, flavonoid glycosides and aglycones in plants (Praven, 2012) and, hence based on this, the present study was carried out for detection of polyphenolic compounds through HPLC. Flavonoids are used abundantly for maximum all types of therapeutic efficacy. Thereafter, it was revealed that good correlations between phenolics content and antioxidant capacity evaluated by different techniques, including HPLC (Brand-Williams et al., 1995; Benzie and Strain, 1999) and, hence an antioxidant study was undertaken for better therapeutic efficacy.

For antioxidant study, DPPH and FRAP assay methods were carried out where methanolic extract showed higher results than aqueous extract. DPPH is a free radical because of its spare electron delocalization over the whole molecule. The donation of $\mathrm{H}^{+}$to the DPPH radicals made a corresponding change from violet colour to pale yellow in the solution. The maximum correlation was observed for antioxidant activity through DPPH assay method with methanolic extract which was similar to the earlier research evidences (Ashafa et al., 2010; Md. Irshad et al., 2012). FRAP assay detects potential antioxidant activity by reacts with a ferric tripyridyltriazine $\left(\mathrm{Fe}^{3+}\right.$ TPTZ) complex and produces a coloured ferrous tripyridyltriazine ( $\mathrm{Fe}^{2+}$-TPTZ) (Gordon, 1990). The reducing properties associated with the presence of compounds exert their action by free radical chain breaking through hydrogen atom (Rice-Evans et al., 1997; Duh et al., 1999). The redox potential of phenolic compounds plays an important role in determining the antioxidant potential and, hence these polyphenolics showed strong antioxidant activity.

Finally, correlation coefficient study revealed and confirmed that methanolic AI extract was better and statistical significant results showed with relation to quercetin and gallic acid estimation, presence of metal ions and their respective antioxidant activity.

\section{Conclusion}

Methanolic extract of $A$. indicum leaves has significant in vitro antioxidant activity, metal ion content and polyphenolic contents. Various phytochemical screening, TLC and HPLC chromatograms resulted for the presence of gallic acid and quercetin and polyphenolic compounds in the methanol extract. Further, this is clear scientific evidence to the possibility of the plant having potential health benefits to cure the diseases in which oxidants have been established as the major key role.

\section{Acknowledgements}

Authors are thankful to Management of Krupanidhi College of Pharmacy for provided laboratory facilities and chemicals to fulfil the present research work and to the Principal, Dr. Amit Kumar Das for his endless encouragement and motivation.

\section{Conflict of interest}

The authors declare that no conflict of interest exists in the course of conducting this research. All authors had final decision regarding the manuscript and the decision to submit the findings for publication.

\section{References}

Adhikari, P.; Pandey, A.; Agnihotri, V. and Pande, V. (2018). Selection of solvent and extraction method for determination of antimicrobial potential of Taxus wallichiana Zucc. Research in Pharmacy, 8: 01-09. doi: 10.25081/rip.2018.v8.3487

Al-Mamoori, F. and Al-Janabi, R. (2018). Recent advances in microwaveassisted extraction (MAE) of medicinal plants: A review. Int. Res. J. Pharm., 9(6):22-29.

Alara, O.R.; Abdurahman, N.H. and Olalere, O.A. (2018). Optimization of microwave-assisted extraction of flavonoids and antioxidants from Vernonia amygdalina leaf using response surface methodology. Food and Bioproducts Processing, 107:36-48.

Ashafa, A.O.T.; Grierson, D.S. and Afolayan, A.J. (2010). In vitro antioxidant activity of extracts from the leaves of Felicia muricata Thunb: An underutilized medicinal plant in the Eastern Cape Province, South Africa. Afr. J. Tradit. Complement Altern. Med., 7(4):296-302.

Balamurugan, G.; Selvarajan, S.; Balakrishnan, D. and Muralidharan, P. (2010). Diuretic activity of Abutilon Indicum Linn (Sweet) seed extract, Journal of Herbal Medicine and Toxicology, 4(1):49-52.

Benzie, F.F. and Strain, J.J. (1999). Ferric reducing/antioxidant power assay: Direct measure of total antioxidant activity of biological fluids and modified version for simultaneous measurement of total antioxidant power and ascorbic acid concentration. Method Enzymol., 299:15-27.

Biradar, R.S. and Rachetti, D.B. (2013). Extraction of some secondary metabolites and thin layer chromatography from different parts of Centella asiatica L. American Journal of Life Sciences, 1(6): 243-247.

Brand-Williams, W.; Cuvelier, M.E. and Berset, C. (1995). Use of a free radical method to evaluate antioxidant activity. LWT-Food Sci Technol., 28:25-30.

Chandrashekhar, V.M.; Nagappa, A.N.; Channes, T.S.; Habbu, P.V. and Rao, K.P. (2000). Antidiarrhoeal activity of Abutilon indicum Linn, Leaf extract. Journal of Natural Remedies, 4(1):12-16.

Chakraborthy, G.S. (2009). Antioxidant activity of Abutilon indicum leaves, International Journal Pharm. Tech. Research, 1(4):13141316.

Chakraborthy, G.S. and Ghorpade, P.M. (2009). Free radical scavenging activity of Abutilon Indicum (Linn) Sweet stem extracts, International Journal of Chem. Tech. Research, 2(1):526-531.

Chen, Y.; Zhang, R.; Liu, C.; Zheng, X. and Liu, B. (2016). Enhancing antioxidant activity and antiproliferation of wheat bran through steam flash explosion. Journal of Food Science and Technology, 53(7):30283034 .

Das, D.K. (2007). Micronutrients: Their behaviour in soils and plants. 2nd revised edn. Kalyani Publishers, New Delhi/ Ludhiana.

Das, K.; Dang, R.; Hegde, L. and Tripathi, A.S. (2011). Assessment of heavy metals in dried Stevia leaves by atomic absorption spectrophotometer grown under various soil conditions. Middle-East Journal of Scientific Research, 8(1):107-113.

Das, K. and Tribedi, S. (2015). Effect of $\mathrm{Zn}, \mathrm{Fe}$ and $\mathrm{Cu}$ content on phytochemical investigations and antimicrobial potential of Alternanthera brasiliana (L.) O. Kuntze leaf extracts procured from two different states of India. Turk. J. Pharm. Sci., 12(3): 345-356. 
Das, K.; Deb, S.; Karanth, T.; Upreti, S. and Dang, R. (2016). Effect of cultural condition on element contents in raw material vis-a-vis impact of solvent nature on estimation of phytochemicals and screening of anthelmintic activity of Melia dubia Cav. leaf. Ann. Phytomed., 5(2):58-68

Das, K.; Dang, R. and Harish, S. (2016). Effect of cultural condition and solvent extraction on pharmacognostical assessment and identification of scopolamine content in different parts of Datura mete Linn. through HPTLC analysis. Ann. Phytomed., 5(1):43-50.

Dashputre, N.L. and Naikwade, N.S. (2010). Immunomodulatory activity of Abutilon Indicum Linn on albino mice. International Journal of Pharma Science and Research, 1(3):178-184.

Dhanani, T.; Shah, S.; Gajbhiye, N.A. and Kumar, S. (2017). Effect of extraction methods on yield, phytochemical constituents and antioxidant activity of Withania somnifera. Arabian Journal of Chemistry, 10: S1193-S1 199.

Duh, P. D.; Du, P. C. and Yen, G. C. (1999). Action of methanolic extract of mungbean hulls as inhibitors of lipid peroxidation and non-lipid oxidative damage. Food and Chemical Toxicology, 37(11):10551061.

Durgawale, P.P.; Patil, M.N.; Joshi, S.A.; Korabu, K.S. and Datkhile, K.D. (2019) Studies on phytoconstituents, in vitro antioxidant, antibacterial, antiparasitic, antimicrobial and anticancer potential of medicinal plant, Lasiosiphon eriocephalus Dence (Family: Thymelaeaceae). J. Nat. Sc. Biol. Med., 10:38-47.

Evans, W.C. (2002). Trease and Evans Pharmacognosy, 15th edition. W.B Sauders Company Ltd, London. pp:137-139, 230-240.

Gordon, M. H. (1990). The mechanism of antioxidant action in vitro, in food antioxidants, B. J. F. Hudson, Ed., pp:1-18, Elsevier Applied Science, London, UK.

Goyal, N.; Singh, S. and Sharma, S.K. (2009). Analgesic effects of various extracts of the root of Abutilon indicum Linn. Journal of Pharmaxy and Bio. Allied Science, 1(1):43-46.

Harborne, J.B. (1998). Phytochemical Methods: A guide to modern techniques of plant analysis. 3rd ed. Chapman and Hall, London ISBN: 0-412-57270-2, pp:302.

Kirtikar, K.R. and Basu, B.D. (1994). Indian Medicinal Plants, Edn 2, Vol. I, Dehradun, 314-317.
Marschner, H. (1995). Mineral nutrition of high plant. Academic Press, pp:330-355.

Md. Irshad.; Md. Zafaryab.; Singh, M. and Rizvi, M.M. A. (2012). Comparative analysis of the antioxidant activity of Cassia fistula extracts. Article ID 157125, 6 pages doi:10.1155/2012/157125.

Mehta, S.; Singh, R.P. and Saklani, P. (2017). Phytochemical screening and TLC profiling of various extracts of Reinwardtia indica. International Journal of Pharmacognosy and Phytochemical Research, 9(4):523-527.

Mousavi, S.R.; Galavi, M. and Rezaei, M. (2013). Zinc (Zn) importance for crop production: A review. International Journal of Agronomy and Plant Production, 4(1):64-68.

Nadakarni, A.K. (1995). Indian Materia Medica, Popular Prakashan (Pvt) Ltd., Bombay, pp:8-9.

Praveen, A. (2012). Identifying and quantifying flavonoids in three medicinal plants by HPLC. International Journal of Innovative Research and Development, 1:344-362.

Raven, J.A.; Evans, M.C.W. and Korb, R.E. (1999). The role of trace metals in photosynthetic electron transport in $\mathrm{O}_{2}$ - evolving organisms. Photosynth. Res., 60:111-149.

Rice-Evans, C. A.; Miller, N. J. and Paganga, G. (1997). Antioxidant properties of phenolic compounds. Trends in Plant Science, 4:304-309.

Rout, G.R. and Sahoo, S. (2015). Role of iron in plant growth and metabolism. Reviews in Agricultural Science, 3:1-24.

Saleh, I.A.; Vinatoru, M.; Mason, T.J.; Abdel-Azim, N.S.; Shams, K.A.; Aboutabl, E. and Hammouda, F.M. (2017). Extraction of silymarin from milk thistle (Silybum marianum) seeds : A comparison of conventional and microwave-assisted extraction methods. Journal of Microwave Power and Electromagnetic Energy, 51(2):124-133.

Sharma, A.; Sharma, R.A. and Singh, H. (2013). Phytochemical and pharmacological profile of Abutilon indicum L. Sweet : A review. Int. J. Pharm. Sci. Rev. Res., 20(1):120-127.

Seetharam, Y.M.; Chalageri, G.; Ramachandra Setty, S. and Bheemachar. (2002). Hypoglycemic activity of Abutilon indicum leaf extracts in rats, Fitoterapia, 73:156-159.

Sulaiman, C.T.; Shahida, V. and Balachandran, I. (2015). Effect of extraction Solvent on the phytoconstituents of Aegle marmelos (L.) Correa. Journal of Natural Remedies., 15(1):58-64.

Citation: Kuntal Das, M. Saifulla Khan, N. Namratha, R. Swetha and Sevgi Gezici (2019). Comparative phytochemical screening, elemental content and chromatographic evaluation for detection and quantification of polyphenolic compounds for strong antioxidant activity of various extracts of Abutilon indicum (Link) Sweet leaves. Ann. Phytomed., 8(1):36-44. 